\title{
Effects of Plants Bioactive Compounds on Foods Microbial Spoilage and Lipid Oxidation
}

\author{
Mohammad Ali Sahari", Sara Asgari \\ Department of Food Technology, Tarbiat Modares University, Tehran, Iran \\ *Corresponding Author: sahari@modares.ac.ir
}

Copyright $@ 2013$ Horizon Research Publishing All rights reserved.

\begin{abstract}
Extracts of many types of plants that are utilized as flavoring and seasoning agents in foods, have been used therapeutically for centuries. Sulphur compounds, terpenes and terpene derivatives, phenols, esters, aldehydes, alcohols and glycosides have shown antimicrobial and antioxidant functions. So far many literatures about the potential use of bioactive phytochemicals in food and pharmacy industries have been published. Thus, this paper reviews some of the works done to evaluate antimicrobial and antioxidant characteristic of some herbal chemicals, carried out in the world.
\end{abstract}

Keywords Antimicrobial and Antioxidant Properties, Plants Bioactive Compounds, Foodstuff

\section{Introduction}

Fruits and vegetables, as active biological sources, contain phytochemicals with antimicrobial, antioxidant, antimutagenic and anticarcinogenic activities. Phytochemicals showing both antioxidant and antimicrobial properties can be used to preserve foodstuffs and increasing their shelf lives. Besides the antimicrobial effect of herbs and spices rich in phenolic compounds, they may preserve foods by reducing lipid oxidation as they are reported to have significant antioxidant activity [1]. Essential oils and plants extracts are known to possess multifunctional properties other than their classical roles as natural food additives. Many essential oils have been confirmed to possess the antioxidant, antibacterial, antifungal and anti-inflammatory activities [2]. Some of the essential oils and their major compounds, used in food systems so as to retard microbial spoilage, are shown in Table 1.

By increasing the consumer's demand for green food products with high safety, quality and nutritional values, it seems that using plants and materials of plant origin such as essential oils and extracts is a suitable way to meet this need.
Natural aromatic plants and spices have been widely used in many food products, dairy and bakery products as flavoring and seasoning agents [3] for preservation and their medicinal value $[4,5]$

Main constituents in spices such as sulphur compounds, terpenes and terpene derivatives, phenols, esters, aldehydes, alcohols and glycosides have shown antimicrobial functions [6-8]. The most important parameters affecting antimicrobial potential are the type and composition of the spice, amount used, type of microorganism, composition of the food, $\mathrm{pH}$ value, temperature of the environment, and proteins, lipids, salts, and phenolic substances in the food system [9].

Aromatic and medicinal plants essential oils as natural additives with potential benefits in food systems showed antibacterial, antifungal and antioxidant efficacies [10]. Antimicrobial properties of some essential oils at low concentrations are extremely higher than food grade organic acids. It has been shown that essential oils have larger efficacy and lower storage temperatures in foods with higher acidities [5]. Although antioxidative and antimicrobial effects of many essential oils have been verified in vitro systems; the same concentrations were not effective in some foodstuffs. For example, some processing procedures such as heating lead to lower efficacy of some essential oils in heated products due to their evaporation [3]. Volatile components of cinnamon leaf, clove, bay, lemongrass and thym essential oils were effective against Eurotium amstelodami, E. herbariorum, E. repens, E. rubrum, Aspergillus flavus, A. niger and Penicillium corylophilum. However, these essential oils weakly performed in case of sponge cake [11]. Gamma irradiation is widely applied in spices to inactivate microbial cells and to prolong their shelf life. Gamma irradiation had no adverse effects on antioxidant and antimicrobial activities and total phenolic content of cinnamon samples. Only at doses more than 10 kGy did the radical scavenging activity of the cinnamon extract increase. Jamshidi et al. (2012) recommended gamma irradiation at doses up to $25 \mathrm{kGy}$ for cinnamon [12]. 
Table 1. Some of the essential oils and their major compounds used in foods systems to retard microbial spoilage

\begin{tabular}{|c|c|c|c|c|c|c|}
\hline $\begin{array}{c}\text { Natural } \\
\text { additives }\end{array}$ & Effective components & Effective against & Known Applications & $\begin{array}{c}\text { Potent } \\
\text { applications }\end{array}$ & Food system & Reference \\
\hline Annatto & $\begin{array}{l}9^{\prime} \text { - cis-norbixin and all } \\
\text { transformed of norbixin }\end{array}$ & $\begin{array}{c}\text { Clostridium } \\
\text { perfringens, Bacillus } \\
\text { cereus, } \\
\text { Staphylococcus } \\
\text { aureus, } \\
\end{array}$ & $\begin{array}{c}\text { Color additive, } \\
\text { antioxidant in } \\
\text { oil-in-water } \\
\text { emulsions }\end{array}$ & $\begin{array}{l}\text { Antimicrobial } \\
\text { activity }\end{array}$ & $\begin{array}{l}\text { Sausage } \\
\text { samples }\end{array}$ & {$[15,16]$} \\
\hline $\begin{array}{l}\text { Amaranthus } \\
\text { spp. seeds }\end{array}$ & $\begin{array}{l}\text { Cichoric acid (diamides), } \\
\text { polysaccharides, alkamides } \\
\text { (alkyl amides) and } \\
\text { glycoproteins }\end{array}$ & $\begin{array}{c}\text { Penicillium } \\
\text { brevicompactum, } P . \\
\text { chermesinum and } \\
\text { Eurotium herbarioum }\end{array}$ & $\begin{array}{c}\text { Astringent, } \\
\text { hemostatic, nutritive, } \\
\text { and alterative }\end{array}$ & $\begin{array}{l}\text { Antifungal } \\
\text { activity }\end{array}$ & Bread & [38] \\
\hline Caraway & $\begin{array}{l}\text { Carvone, limonene and } \\
\text { (E)-anethole }\end{array}$ & $\begin{array}{l}\text { Rice pests (Sitophilus } \\
\text { oryzae, Rhyzopertha } \\
\text { dominica and } \\
\text { Cryptolestes pusillus) }\end{array}$ & $\begin{array}{l}\text { Colds, colic, coughs, } \\
\text { flatulence, } \\
\text { indigestion, poor } \\
\text { appetite, stomach } \\
\text { cramps treatments, } \\
\text { flavoring agent, } \\
\text { soap and lotion } \\
\text { production } \\
\end{array}$ & $\begin{array}{l}\text { Effective } \\
\text { against pests }\end{array}$ & Rice & {$[56]$} \\
\hline Cinnamon & Cinnamaldehyde & $\begin{array}{c}\text { Escherichia coli, } \\
\text { Enterobacteriaceae, } \\
\text { B. cereus, } \\
\text { coagulase-positive } \\
\text { Staphylococci }\end{array}$ & $\begin{array}{l}\text { Snakebites, freckles, } \\
\text { the common cold, } \\
\text { and kidney troubles } \\
\text { treatments, } \\
\text { flavoring agent and } \\
\text { preservative }\end{array}$ & $\begin{array}{l}\text { Antimicrobial } \\
\text { activity }\end{array}$ & Kolompe & [40] \\
\hline Coriander & $\begin{array}{c}\text { Linalool, } \\
\text { camphor, cyclohexanol } \\
\text { acetate, limonene and } \\
\alpha \text {-pinene }\end{array}$ & $\begin{array}{l}\text { Rice pests (Sitophilus } \\
\text { oryzae, Rhyzopertha } \\
\text { dominica and } \\
\text { Cryptolestes } \\
\text { pusillus), } \\
\text { gram positive and } \\
\text { gram negative } \\
\text { bacteria, fungi } \\
\end{array}$ & $\begin{array}{l}\text { Anorexia, dyspepsia, } \\
\text { flatulence, diarrhea, } \\
\text { griping pain and } \\
\text { vomiting treatment, } \\
\text { flavoring agent } \\
\text { perfumes } \\
\text { cosmetics }\end{array}$ & $\begin{array}{c}\text { Effective } \\
\text { against pests, } \\
\text { antioxidant } \\
\text { and } \\
\text { antifungal } \\
\text { activities }\end{array}$ & $\begin{array}{l}\text { Rice, } \\
\text { cake }\end{array}$ & $\begin{array}{c}{[56]} \\
{[33,35]}\end{array}$ \\
\hline $\begin{array}{l}\text { Lavandula } \\
\text { angustifolia } \\
\text { essential oil }\end{array}$ & $\begin{array}{l}\text { Linalool, camplhore, } 1,8 \\
\text { cineol, inalol acetat, borneol } \\
\text { and } \alpha \text {-terpineol }\end{array}$ & $\begin{array}{c}\text { S. aureus, E. coli, } \\
\text { coliforms, molds and } \\
\text { yeasts }\end{array}$ & $\begin{array}{c}\text { Acne, allergies, } \\
\text { burns (cell renewal), } \\
\text { and cramps } \\
\text { treatment, } \\
\text { lotions } \\
\text { bath oils } \\
\end{array}$ & $\begin{array}{l}\text { Antioxidant } \\
\text { and } \\
\text { antimicrobial } \\
\text { agent }\end{array}$ & $\begin{array}{l}\text { Butter milk, } \\
\text { soybean oil }\end{array}$ & {$[44,71]$} \\
\hline $\begin{array}{l}\text { Echinacea } \\
\text { purpurea } \\
\text { extract }\end{array}$ & $\begin{array}{c}\text { Phenolic compounds such as } \\
\text { chicoric acid, caffeic and } \\
\text { chlorogenic }\end{array}$ & $\begin{array}{c}\text { E. coli, } \\
\text { Enterobacteriaceae, } \\
\text { B. cereus, } \\
\text { coagulase-positive } \\
\text { Staphylococci }\end{array}$ & $\begin{array}{l}\text { Immunostimulant, } \\
\text { anticarcinogenic, } \\
\text { common cold, } \\
\text { influenza, } \\
\text { respiratory and } \\
\text { urinary treatment, } \\
\text { ingredient in } \\
\text { functional foods, } \\
\text { supplements and } \\
\text { certain candies } \\
\end{array}$ & $\begin{array}{l}\text { Antioxidant } \\
\text { and } \\
\text { antimicrobial } \\
\text { activities }\end{array}$ & Kolompe, & {$[40,63]$} \\
\hline $\begin{array}{l}\text { Eremophila } \\
\text { alternifolia } \\
\quad \text { and } \\
\text { Eremophila } \\
\text { duttonii } \\
\end{array}$ & Terpenes or sterols & $\begin{array}{l}\text { Listeria } \\
\text { monocytogenes }\end{array}$ & $\begin{array}{c}\text { Colds and } \\
\text { inflammation of the } \\
\text { throat treatment }\end{array}$ & $\begin{array}{l}\text { Antimicrobial } \\
\text { activity }\end{array}$ & $\begin{array}{c}\text { Full cream milk } \\
\text { and skim milk }\end{array}$ & [46] \\
\hline $\begin{array}{l}\text { Mango seed } \\
\text { kernel oil }\end{array}$ & Phenolic compounds & Coliforms & & $\begin{array}{l}\text { Antioxidant } \\
\text { and } \\
\text { antimicrobial } \\
\text { activities } \\
\end{array}$ & $\begin{array}{c}\text { Sunflower oil, } \\
\text { potato chips, } \\
\text { pasteurized } \\
\text { cow milk } \\
\end{array}$ & {$[32,33]$} \\
\hline Tea seed oil & $\begin{array}{l}\text { (-)-epigallocatechin-3-gallate } \\
\text { (EGCG), } \alpha \text {-tocopherol, and } \\
\text { tocotrienols }\end{array}$ & $\begin{array}{c}\text { B. cereus and } S \text {. } \\
\text { aureus }\end{array}$ & & $\begin{array}{l}\text { Antioxidant } \\
\text { and } \\
\text { antimicrobial } \\
\text { activity }\end{array}$ & $\begin{array}{c}\text { Marine oil, } \\
\text { common kilka } \\
\text { (Clupeonella } \\
\text { cultriventris } \\
\text { caspia), cooked } \\
\text { red meat, } \\
\text { poultry and fish } \\
\text { patties, rice } \\
\text { cake }\end{array}$ & $\begin{array}{l}{[22,43} \\
51,65, \\
66,67 \\
68]\end{array}$ \\
\hline
\end{tabular}


In many cases, bioactive compounds could be produced of inexpensive sources or totally agricultural wastes, which can provide economic and highly available sources from co-products during a typical processing procedure. Rajaei et al. (2010) studied antioxidant, antimicrobial and antimutagenicity activities of pistachio (Ahmadaghaei variety) green hull extract (crude and purified extracts). The results obtained by 2, 2'-Azinobis (3-ethylbenzothiazoline-6-sulfonate) diammonium salt (ABTS) assay, 2, 2'-diphenyl 1-picrylhydrazyl (DPPH) assay and $\beta$-carotene bleaching (BCB) method indicated that pistachio green hull aqueous extracts presents a strong antioxidant activity. Furthermore, inhibition of the growth of the different pathogenic bacteria $\left(\mathrm{Gram}^{+}\right)$and antimutagenicity by pistachio green hull extract. The results of disc diffusion test showed that Bacillus cereus was the most susceptible one with minimum inhibitory concentration (MIC) of 1 and $0.5 \mathrm{mg} \mathrm{mL} \mathrm{m}^{-1}$ for the crude and purified extracts, respectively [13].

\section{Food Applications}

Although various plant extract compositions, trial methods and microorganisms under test make it difficult to compare data from different studies [11], due to development of the natural antioxidants used in food industries, here we emphasize the antimicrobial properties of some medicinal plants, focusing on their applications in different food types.

\subsection{Meat Products and Fish}

Meat, fish and poultry products are highly susceptible to spoilage. Since ancient times, different methods have been developed to preserve these products including: pickling, drying, salting, freezing and canning. However, in recent years, there is an upsurge of interest in natural bioactive compounds originated in traditional medicinal plants due to their low cost and abundant sources and verification of their antioxidant and antimicrobial activities against common pathogens. Therefore, many researchers focused on antimicrobial and antioxidant activities of natural compounds in spices commonly used in meat, fish and poultry products. Cinnamon essential oil is extracted from bark and leaves of Cinnamomum verum. The presence of cinnamaldehyde and eugenol in cinnamon essential oil is found to be key antioxidant and antimicrobial chemical compounds. It showed antimicrobial activity against Staphylococcus aureus, Klebsiella pneumoniae, Pseudomonas aeruginosa, Enterococcus faecalis, Micrococcus luteus, Escherichia coli and Candida albicans as common meat spoilage and pathogenic microorganisms [14]. Annatto, a food coloring and flavoring agent used in meat and fish products, is extracted from pericarp of the achiote (Bixa orellana L.). Evaluation of the inhibitory effect of annatto extract on growth ability and spore germination of
Clostridium perfringens, B. cereus, S. aureus and E. coli in chemical medium and in sausage sample, showed antibacterial potential of this extract against $C$. perfringens, $B$. cereus and $S$. aureus. However, no activity was detected against $E$. coli. In addition annatto was capable to inhibit spore germination and outgrowth of $C$. perfringens and $B$. cereus. In sausage samples with nitrite alone or in combination with nitrite at $20^{\circ} \mathrm{C}$, no germination of spores were observed [15]. Concerning the effective part in creating antimicrobial effect, literature shows that $9^{\prime}$-cis-norbixin and all transformed of norbixin are capable to create this characteristic [16].

Antimicrobial activities of garlic oil and nine constituents of essential oils (allyl isothiocyanate, carvacrol, cinnamaldehyde, citral, cuminnaldehyde, eugenol, isoeugenol, linalool and thymol) were evaluated against 16 bacterial strains isolated from common carp (Cyprinus carpio), by paper disc diffusion method. The most effective compounds against this microflora were thymol, carvcarol and cinnamaldehyde followed by isoeugenol, eugenol, garlic oil, and citral, while cuminnaldehyde, linalool and allyl isothiocyanate exhibited lower efficacy. An equal mixture of carvacrol and thymol solution, before storage at $5^{\circ} \mathrm{C}$ and $10^{\circ} \mathrm{C}$, reduced the total count by about 100 -fold in carp fillets and reduced the volatile base nitrogen. A concentration of $1 \%$ of carvacrol-thymol mixture solution inhibited bacterial growth and extended the shelf life of the dipped fillets by 8 and 4 days at low temperature over $5^{\circ} \mathrm{C}$ and $10^{\circ} \mathrm{C}$ storage, respectively [17].

Growth of Photobacterium phosphoreum has been inhibited by oregano oil in liquid medium and in naturally contaminated vacuum packed cod fillets at $2^{\circ} \mathrm{C}$ and an increase in shelf life by 10-14 days has been successfully achieved [18]. Synergistic effect of modified atmosphere packaging with essential oils against spoilage bacteria has been used to extend shelf life of food products. Similarly, Chouliara et al. (2007) reported that combination of modified atmosphere packaging and oregano essential oil could remarkedly reduce microbial population by 1-5 log $\mathrm{cfu} / \mathrm{g}$ in fresh chicken meat [19]. Antimicrobial properties of turmeric extract and shallot extract was examined both individually and in combination (1:1) on the quality of vacuum-packaged rainbow trout during refrigerated storage. Combined treatment of both turmeric and shallot extracts provided a hurdle technology for protecting the rainbow trout from the risk of pathogenic microorganism [20].

The most abundant water-soluble antioxidant vitamin that can react with superoxide radicals, hydrogen peroxide, hydroxyl radicals and single oxygen through Hydrogen Atom Transfer and remove reactive oxygen species is ascorbic acid [21]. Ojagh et al. (2011) examined the antioxidant effects of $\beta$-carotene in con centration of 100 , 200 , and 300 ppm combined with ascorbic acid (0.1, 0.2 and $0.3 \mathrm{~g}$, respectively as a synergist agent) and green tea polyphenols in concentration of 200, 400 and 600 ppm on the quality of common kilka (Clupeonella cultriventris caspia) 
during the storage with ice powder. According to the results, the $\beta$-carotene 100 and green tea polyphenols 200 samples produced the best preservation condition, while they did not have any significant difference in their qualitative characteristics (color, odor, texture, taste and flavor as well as off-flavor) [22]. Also, addition of concentrations greater than $300 \mathrm{mg} \mathrm{kg}^{-1}$ of tea catechins considerably reduced oxidation rate in patties [23].

Karpińska et al. (2001) reported that application of 1.5\% of sage alone was more effective on turkey meat dish storage stability than the $1 \%$ mixture of spices (sage, red pepper, black pepper, garlic and marjoram). The quality of products with $1.5 \%$ sage was good after a-four-day storage in refrigerator [24].

Black cumin (Nigella sativa) is a medicinal seed, native to South and Southwest of Asia. Its antifungal and antibacterial effects have been studied by many researchers. Treatment with ethanolic extract of $N$. sativa reduced aerobic plate count, yeast, and coliforms in marinated raw trout (Oncorhynchus mykiss) [1].

Listeria monocytogenes is a gram-positive, psychrotrophic and facultative anaerobic bacterium, which causes the infection Listeriosis. Meats and fish products are known as food sources that have sometimes led to Listeriosis outbreaks. Application of oregano and cranberry extracts (75:25) against $L$. monocytogenes in vitro and in beef and fish showed good inhibitory effect. Combination of these phytochemicals with lactic acid was also found more effective when beef and fish slices were stored at $4^{\circ} \mathrm{C}$ [25]. Micromelum minutum and Artocarpus heterophyllus could effectively suppress $L$. monocytogenes in cooked pork at the storage temperature of $4^{\circ} \mathrm{C}$ for up to 7 days [26].

Rosemary has been extensively investigated for its antioxidant potent [27]. A mixture of aqueous extract of rosemary, sage and thyme was successfully used in marinated turkey thigh to prevent rancidity during storage [28]. Combination of Scutellaria, honeysuckle, forsythia and cinnamon and mixture of cinnamon, rosemary and clove oil reduced microbial counts from 1.81 to 2.32-log as compared to control in vacuum packaged fresh pork during 28 days storage [1].

Antimicrobial, antiradical and antioxidant activities of pomegranate peel extract have been shown. It possessed good antimicrobial activity against $S$. aureus and B. cereus at concentration of $0.01 \%$. Addition of this extract to chicken meat products enhanced their shelf life by $2-3$ weeks during chilled storage [29].

\subsection{Bakery Products}

Major microbial spoilage in bakery products is mold growth resulting in economic losses. Therefore, numerous techniques have been implemented to prevent or control the growth of spoilage microorganisms and enhance shelf life of food products. Various types of spices are used in bakery industries mainly to improve taste and flavor. Recently, a large number of these ingredients have demonstrated antimicrobial and antioxidant activities. Kordsardoui et al. (2011) studied antifungal properties of Zataria multiflora Boiss essential oil (ZMEO) in cake. This plant is one of the important species of Labiatae family, which is widely used as nutritional flavoring. According to this study, application of ZMEO at concentrations of 500, 1000 and $1500 \mathrm{ppm}$ reduced mold counts significantly during cake batter production [30]. According to Zangiabadi et al. (2012) total phenolic contents of ZMEO was $322 \mathrm{mg} \mathrm{ml}^{-1}$ by Folin-Ciocalteu [31].

Recently, many studies proved that mango seed kernels possess antioxidant activity due to their different phenolic compounds [32]. Bakery products prepared with mango dietary fiber concentrate of unripe fruit, possessed most of its antiradical efficiency [33].

Coriander is the common name of Coriandrum sativum also known as Chinese parsley. Coriander essential oil (CEO) has been found to exhibit antioxidant and antimicrobial effects. It has been revealed that $\mathrm{CEO}$ at $0.05,0.10$ and $0.15 \%$ prevented the primary and secondary oxidation products formation, and at $0.15 \%$ level, it inhibited fungal growth in cake. Chemical composition of CEO mainly consists of camphor $(44.99 \%)$, cyclohexanol acetate (cis-2-tert butyl-) (14.45\%), limonene (7.17\%), $\alpha$-pinene (6.37\%). Antioxidant effects of this essential oil may be due to its trepene and terpenoid components [34]. Another study demonstrated antimicrobial activity of CEO against five species of Candida albicans [35]. Also, it is reported that coriander essential oil has pronounced antibacterial activity against both Gram positive (S. aureus and Bacillus spp.) and Gram negative (E. coli, Salmonella typhi, K. pneumonia and Proteus mirabilis) bacteria. In addition, this extract showed anthelmintic activities against Haemonchus contortus [34]. Several researchers have described the antifungal activity of limonene, a terpenoid hydrocarbon isolated from coriander, against Aspergillus niger. According to Darughe et al. (2012) this essential oil could be used as natural antioxidant and antifungal in foodstuffs especially those lipid containing [34].

Echinacea purpurea L. extract was found to be effective in controlling growing molds and lipid oxidation during 60 days storage at $25^{\circ} \mathrm{C}$. According to antimycotic evaluation, $1000 \mathrm{ppm}$ of the extract showed greater antioxidant activity than $200 \mathrm{ppm}$ BHA, and at concentrations of 1500 and 2000 ppm had an excellent antifungal effect on cake [36]. Noorolahi et al. (2013) also reported that 0.5 and $0.75 \%$ of $E$. purpurea extract showed very well preventing power on aerobic microorganism, yeast and molds [40].

Most important spoilage molds in cakes and bakery products are Rhizopus stolonifer, Penicillium expansum, $P$. stoloniferum, A. niger, Monilia sitophila and species of Mucor and Geotrichum. Lean and Mohamed (1999) indicated that turmeric showed antioxidant and antimycotic activities in butter cake [37]. In another study by Rizzello et al. (2009), common spoilage microorganisms in bread were inhibited by water-soluble extract of Amaranthus spp. seeds and it was indicated that may be also exerted as sensory 
improving agent in wheat and gluten-free breads [38].

Rice bran is the byproduct of rice milling process. It is a rich source of important phytochemicals resulting in its significant antioxidant property. Among all phytochemicals, oryzanol, tocopherols and tocotrienols are considered the most powerful ones. Bhanger et al. (2008) reported that 500, 1000 and $2000 \mathrm{ppm}$ of methanolic extracts of rice bran could successfully increase induction period from 7.5 hours to 14.73-31.22 hours in cookies [39].

Chamomile essential oil as a natural antioxidant and antimicrobial agent can increase shelf life of food products. Fungicidal effect of $0.15 \%$ of chamomile essential oil during 75 days of storage of cake was observed by Khaki et al. (2012) and it was reported that with increasing the concentration of chamomile essential oil, inhibitory activity would increase, and also, after 75 days, growth of molds was observed in all samples [41]. In another study, they investigated neroli essential oil in cake. Application of 0.05 , 0.1 and $0.15 \%$ of this essence had a positive effect against $E$. coli, coliforms, S. aureus, Enterobacteriaceae, molds and yeasts [42].

Reddy et al. (2005) used three plant foods amla (Emblica officianalis), drumstick leaves (Moringa oleifera) and raisins (Vitis vinifera) as natural antioxidant sources in biscuits. Extracts from drumstick leaves and amla had more influence on controlling lipid oxidation during storage. Plant extracts from the three plant foods had pronounced antioxidative effect on biscuits after 6 weeks compared with the effect of BHA [4].

As described by Lee et al. (2009), 1 or $3 \%$ green tea or rosemary leaf powders added to rice cakes did not significantly reduce total aerobic counts. But levels of $B$. cereus and $S$. aureus were significantly reduced in rice cakes stored for 3 days at room temperature $\left(22^{\circ} \mathrm{C}\right)$. Individual leaf powders of green tea and rosemary at $3 \%$ level had the strongest inhibitory effect, followed by $1 \%$ green tea and $1 \%$ rosemary leaf powder, respectively [43].

\subsection{Dairy Products}

The effect of Lavandula angustifolia essence on some microbial parameters of butter milk preservation was studied. This essence was successfully used as natural antimicrobial against $S$. aureus, E. coli, coliforms, molds and yeasts [44]. Investigation of mango seed kernel extract on pasteurized cow milk indicated that it had the potent to reduce total bacterial count and inhibited the growth of coliforms resulting in longer shelf life [1]. Oregano and thyme showed less antimicrobial effect against $L$. monocytogenes compared to Pseudomonas fluorescens on milk model media [45]. According to a study by Owen and Palombo (2007), the presence of fat in full cream milk could significantly reduce the antibacterial activity of whole plant extracts of Eremophila alternifolia and $E$. duttonii against $L$. monocytogenes compared to skim milk [46].

Ziziphora clinopodioides (with folk name of Kakuti-e Kuhi) is one of four species of Ziziphora $L$. It is widely grown in Iran and used as flavoring agent and in traditional medicine. Antioxidant and antimicrobial properties of the essential oil have been shown. A $4000 \mu \mathrm{g} \mathrm{L}^{-1}$ level of Ziziphora clinopodioides extract noticeably reduced the growth of yogurt starter culture [47]. Study on effect of mint extract in a native Iranian dairy drink containing probiotic bacteria, biodoogh, indicated a concentration dependent effect on the viability of probiotic strains [48].

\subsection{Fruit and Vegetable Juices}

Investigation of $E$. coli $\mathrm{O} 157: \mathrm{H7}$ inoculated in apple juice indicated that carvacrol, oregano oil, geraniol, eugenol, cinnamon leaf oil, citral, clove bud oil, lemongrass oil, cinnamon bark oil, and lemon oil had the most effective compounds and Melissa oil, carvacrol, oregano oil, terpeineol, geraniol, lemon oil, citral, lemongrass oil, cinnamon leaf oil and linalool had good antimicrobial potent against Salmonella enterica [49].

Storage temperature is one of the most important parameters affecting antioxidant and antimicrobial activities of bioactive components. Increasing the temperature from 45 to $50^{\circ} \mathrm{C}$ could significantly enhance mint extract efficacy in tomato juice [50].

Antimicrobial activity of koruk (Vitis vinifera) juice against two Salmonella typhimurium strains was determined in inoculated cucumber and parsley samples. Although koruk juice led to an instant reduction in initial total count, treatment for 15,30 and 60 minutes did not differ significantly regarding reduction in total count [51].

Hippophae rhamnoides (known as sea buckthorn), owned by Elaeagnaceae family, is reputed to be an antioxidant-rich source. Ascorbic acid was reported to be the major antioxidant compound in sea buckthorn juice. The phenolic composition of sea buckthorn berry-like fruit juice was investigated. Flavonols were found to be the predominating polyphenols while phenolic acids and catechins represent minor components [52].

\subsection{Sauces}

Satureja hortensis L. belongs to Lamiaceae family and is well known in Iranian traditional medicine. The formulated mayonnaise prepared by the mixture of linseed and soybean oil and amended with ZMEO and Satureja hortensis L. essential oil (SHEO), showed that these natural antioxidants in mayonnaise formulation can ameliorate the quality of product as functional food due to advancing the public health [53].

"Tarkhun" and "Babune Shirazi" are the Persian names for Artemisia dracunculus L. and Matricaria chamomilla L., respectively, belonging to the family Asteraceae and are commonly used as condiment for sauces. The essential oil of Tarkhun is said to be a neuromuscular antispasmodic, anti-inflammatory, and used in aerophagy, spasmodic colitis, and as antibacterial and antifungal agent. M. chamomilla L. essential oil has been used commonly in medicine as an 
anti-inflammatory, antispasmodic, anti-intestinal bloating, anti-pectic ulcer, anti-bacterial and anti-fungal [54].

Garlic has been used as a food additive and medicinal plant for thousands years. Scientific literature on garlic suggests different potentially beneficial effects on human health due to its related compounds. Study on antimicrobial effect of garlic against $S$. enterica serovar enteritidis showed $1 \%$ garlic decreased the viable cells in mayonnaise contaminated with $105 \mathrm{cfu} \mathrm{g}^{-1} S$. enterica serovar enteritidis by a factor of 10 [55].

\subsection{Cereals}

The usefulness of bioactive compounds included essential oils as insecticides has been reported and traditionally implemented to protect grains against pests during storage by some countries. Lopez et al. (2008) investigated efficacy of essential oils of coriander, caraway and basil against stored rice pests (Sitophilus oryzae, Rhyzopertha dominica and Cryptolestes pusillus). The major effective compound in coriander oil was linalool at $1617 \mathrm{ppm}$ against the three pests. Camphor-rich fractions significantly affected $R$. dominica and C. pusillus at concentrations greater than $400 \mathrm{ppm}$. Caraway extract included carvone, limonene and (E)-anethole as major constituents. Carvone and (E)-anethole were highly effective against $S$. oryzae and $R$. dominica, respectively, whereas only adults of $C$. pusillus were negatively affected by vapors of limonene [56].

\subsection{Fruits and Vegetables}

It is supposed that essential oils in vegetable dishes have better antimicrobial activity due to their low fat content [57]. Carvacrol and cinnamaldehyde exhibited higher potent in reducing the population of the natural flora on kiwifruit dipped in $0.15 \mu \mathrm{l} \mathrm{ml}^{-1}$, than on honeydew melon. This difference probably emerged from the difference in $\mathrm{pH}$ between the fruits; the $\mathrm{pH}$ of kiwifruit was 3.2-3.6 and of the melon 5.4-5.5, i.e., essential oils and their constituents perform better in higher acidities [57].

Essential oil components that have been tested on vegetables appear effective against the natural flora and food-borne pathogens at levels of $0.1-10 \mu \mathrm{g} \mathrm{g}^{-1}$ in washing water. Cinnamaldehyde and thymol are effective against six Salmonella serotypes on alfalfa seeds (application in hot air at $50^{\circ} \mathrm{C}$ as fumigation). Efficacy of these natural antibacterial compounds decreased with increasing the temperature to $70^{\circ} \mathrm{C}$. As indicated once, it may be due to evaporation of the effective compounds. Oregano oil showed inhibitory effect against $E$. coli $\mathrm{O} 157: \mathrm{H} 7$ at concentrations of $7-21 \mu \mathrm{g} \mathrm{g}^{-1}$ in eggplant salad [57]. Spice hydrosols have been used due to their low cost and easiness of application especially in beverage industries for a long time. Thyme hydrosols produced a reduction of more than $1 \log \mathrm{cfu} \mathrm{g}^{-1}$ of E. coli $\mathrm{O} 157: \mathrm{H} 7$ and S. typhimurium number on inoculated apples and carrots. Overall, thyme hydrosol was more effective against $S$. typhimurium compared to $E$. coli
O157:H7 on carrot samples with maximum reduction of 1.48 $\log \mathrm{cfu}^{-1}$ in S. typhimurium population [58].

\subsection{Food Packaging}

Basil (Ocimum basilicum L.) is a popular culinary herb, and its essential oils have been used as aroma additives in food, pharmaceuticals, and cosmetics [59]. Antimicrobial efficacy of Basil essential oils and their major components against a wide range of Gram-negative and Gram-positive bacteria, yeast, and mold has been proved. Suppakul et al. (2003) evaluated its potential in active food packaging [60]. Edible films on milk protein-base containing oregano, pimento, or oregano/pimento showed antibacterial properties against E. coli $\mathrm{O} 157: \mathrm{H} 7$ and Pseudomonas sp. on meat surfaces [61].

Nielsen and Rios (2000) investigated a mixture of spices and herbs as an alternative to active packaging for bread. The essential oils of mustard were the most effective followed by cinnamon, garlic and clove. However, oregano oleoresin and vanilla essential oil had weak activity and no inhibitory potent against most important spoilage fungi of bread, respectively [62].

\subsection{Oil Systems}

There are a lot of studies which proved the efficacy of essential oils in oil systems. Table 2 shows some of these investigations conducted medical plants application in different crude oils.

Hyssopus officinalis L. and Echinacea purpurea L. could be appropriate natural alternatives to synthetic antioxidants in soybean oil system. According to three DPPH, $\mathrm{ABTS}^{+}$ and beta carotene bleaching tests, the antioxidant activity of Hyssopus officinalis L. was greater than of Echinacea purpurea L. extract in soybean oil [63]. Oxidation rate of soybean oil reduced by Artemisia dracunculus L. and Matricaria chamomilla L. essential oils under accelerated conditions at $60 \square \mathrm{C}$ (oven test) [54]. Likewise, dill (Anethum graveolens Boiss) with the vernacular name of shebet in Iran was found effective in inhibition of oxidation in crude soybean oil at $0.6 \mathrm{mg} \mathrm{ml}^{-1}$ concentration, suggesting that it could provide a good alternative to synthetic antioxidants [64].

According to investigations, the antioxidant activity of tea seed oil is mainly due to (-)-epigallocatechin-3-gallate (EGCG), $\alpha$-tocopherol, and tocotrienols [65] and even, its antioxidant properties increased during the roasting process [21]. According to Wanasundara and Shahidi (1996) antioxidative activity of tea catechins is similar to or better than that of synthetic antioxidants [66]. Decholrophylized green tea extract was found to have antioxidative activity in marine oils; however, green tea extracts exhibited a prooxidant effect [67]. Fazel et al. (2009) applied tea and sesame seed oils as two natural antioxidants to a fish oil model system and compared them by radical scavenging activity. The results revealed that radical scavenging activity 
of sesame seed oil was higher than that of tea seed oil $\left(\mathrm{IC}_{50}=37 \mathrm{mg}\right.$ and $45 \mathrm{mg}$, respectively). However, after 6 days at $60 \mathrm{C}$, the radical scavenging activity values of tea and sesame seed oils were the same [68].

Essential oil of Zataria multiflora Boiss containing carvacrol $(26.08 \%)$ and thymol $(17.23 \%)$ as main phenolic components showed good antioxidant activity in soybean oil [5]. However, in another study, ZMEO (1000 ppm) and SHEO (200 ppm) showed less antioxidant effect compared to BHA (200 ppm) as a synthetic antioxidant [69]. On the other hand, SHEO inhibited oxidation in safflower oil [70].
Linalool, camphore, 1, 8-cineol, inalol acetat, borneol and $\alpha$-terpineol are six major bioactive components in Lavandula angustifolia essential oil reported to have antiradical activities in crude soybean oil [71]. Similarly, Malva sylvestris L. essence has shown antioxidant potential with maximum antiradical activity related to the $10 \mathrm{mg} / \mathrm{ml}$ of this essence [72]. Studies showed $400 \mathrm{ppm}$ methanol extract and $5 \%$ mango seed kernel oil increased stability of sunflower oil both in ambient and in frying temperature against oxidation. Also, this mixture could increase oxidative stability and quality characteristic of potato chips [32].

Table 2. Some medical plants applications in different crude oil

\begin{tabular}{|c|c|c|c|c|c|}
\hline Family & Latin name & $\begin{array}{l}\text { Persian/Local } \\
\text { name }\end{array}$ & $\begin{array}{l}\text { Assays for determining antioxidant } \\
\text { activity }\end{array}$ & Trial oil & Reference \\
\hline Apiaceae & $\begin{array}{c}\text { Anethum graveolens } \\
\text { Boiss }\end{array}$ & Shebet & $\mathrm{DPPH}^{\circ}$ and beta carotene bleaching & Soybean oil & {$[64]$} \\
\hline Asteraceae & $\begin{array}{c}\text { Echinacea purpurea } \\
\text { L. }\end{array}$ & $\begin{array}{c}\text { Purple } \\
\text { coneflower } \\
\text { (Sarkhargol) } \\
\end{array}$ & $\begin{array}{c}\mathrm{DPPH}^{*}, \mathrm{ABTS}^{+} \text {and beta carotene } \\
\text { bleaching }\end{array}$ & Soybean oil & {$[63]$} \\
\hline Asteraceae & $\begin{array}{c}\text { Matricaria } \\
\text { chamomilla L. }\end{array}$ & Babune Shirazi & $\mathrm{DPPH}^{\circ}$ and beta carotene bleaching & Soybean oil & {$[54]$} \\
\hline Labiatae & $\begin{array}{l}\text { Hyssopus officinalis } \\
\text { L. }\end{array}$ & Zoofa & $\begin{array}{c}\mathrm{DPPH}^{*}, \mathrm{ABTS}^{++} \text {and beta carotene } \\
\text { bleaching }\end{array}$ & Soybean oil & [63] \\
\hline Labmiaceae & $\begin{array}{l}\text { Lavandula } \\
\text { angustifolia }\end{array}$ & Ostokhodus & $\begin{array}{c}\mathrm{DPPH}^{*}, \mathrm{ABTS}^{++} \text {and beta carotene } \\
\text { bleaching }\end{array}$ & Soybean oil & {$[71]$} \\
\hline $\begin{array}{l}\text { Labmiaceae } \\
\text { (Labiatae; } \\
\text { minths) }\end{array}$ & Satureja hortensis L. & Marze & $\begin{array}{l}\text { Specific absorbance at } 232 \text { and } 270 \\
\mathrm{~nm} \text { (conjugated dienens and trienes) } \\
\mathrm{DPPH}^{\circ}, \mathrm{ABTS}^{++}, \text {ferric thiocyanate } \\
\text { and beta carotene bleaching } \\
\text { Conjugated dienens and peroxide } \\
\text { value }\end{array}$ & $\begin{array}{l}\text { Soybean oil } \\
\text { Safflower oil } \\
\text { Linseed oil }\end{array}$ & $\begin{array}{l}{[69]} \\
{[70]} \\
{[53]}\end{array}$ \\
\hline Labiatae & $\begin{array}{l}\text { Zataria multiflora } \\
\text { Boiss }\end{array}$ & Avishan & $\begin{array}{c}\text { Specific absorbance at } 232 \text { and } 270 \\
\mathrm{~nm} \text { (conjugated dienens and trienes), } \\
\text { peroxide value } \\
\mathrm{DPPH}^{\circ} \text { and beta carotene bleaching } \\
\text { Conjugated dienens and peroxide } \\
\text { value }\end{array}$ & $\begin{array}{l}\text { Soybean oil } \\
\text { Soybean oil } \\
\text { Linseed oil }\end{array}$ & $\begin{array}{l}{[5]} \\
{[53]}\end{array}$ \\
\hline Malvaceae & Malva sylvestris $\mathrm{L}$. & Panirak & $\begin{array}{c}\mathrm{DPPH}^{*}, \mathrm{ABTS}^{+} \text {and beta carotene } \\
\text { bleaching }\end{array}$ & Soybean oil & {$[72]$} \\
\hline
\end{tabular}




\section{Conclusion}

Natural antioxidants and antimicrobials can improve shelf life of food products, and due to absence of synthetic agents, these compounds are safe without any side effects on human health. Antimicrobial activity of plant extracts is frequently due to the essential oil fraction or to sulfur-containing compounds in the aqueous phase. The composition, structure and functional groups in oils play an important role in determining their antimicrobial activity. Results of different studies indicate that herbal bioactive compounds can act as good replacers of synthetic antioxidant and preservatives.

\section{REFERENCES}

[1] P. S. Negi. Plant extracts for the control of bacterial growth: efficacy, stability and safety issues for food application, International Journal of Food Microbiology, Vol.156, 7-17, 2012.

[2] N. Shahsavari, M. Barzegar, M. A. Sahari, H. Naghdidadi. Antioxidant activity and chemical characterization of essential oil of Bunium persicum, Plant Foods for Human Nutrition, Vol.63, 183-188, 2008.

[3] M. Elgayyar, F. A. Draughon, D. A. Golden, J. R. Mount. Antimicrobial activity of essential oils from plants against selected pathogenic and saprophytic microorganisms, Journal of Food Protection, Vol.64, No.7, 1091-1024, 2001.

[4] V. Reddy, A. Urooj, A. Kumar. Evaluation of antioxidant activity of some plant extracts and their application in biscuits, Food Chemistry, Vol.90, 317-321, 2005.

[5] N. Shahsavari, M. Barzegar, M. A. Sahari, H. Naghdiabadi. An investigation on the antioxidant activity of essential oil of Zataria multiflora Boiss in soybean oil, Journal of Medicinal Plants, Vol.28, 56-68, 2006.

[6] R. J. Russel G. W. Gould. Food Preservatives, Van Nostrand Reinhold Co., New York, 1991.

[7] P. M. Davidson, A. L. Baren. Antimicrobials in Foods. Marcel Dekker, New York, 1993.

[8] R. D. Deis. Secret world of spices, Food Product Design, Vol.5, 1-7, 1999.

[9] O. Sagdic. Sensitivity of four pathogenic bacteria to Turkish thyme and wild marjoram hydrosols. LWT, Lebensmittle-Wissenschaft and Technologie, Vol.36, 467-473, 2003.

[10] O. Politeo, M. Jukic, M. Milos. Chemical composition and antioxidant capacity of free volatile aglycones from basil (Ocimum basilicum L.) compared with its essential oil, Food Chemistry, Vol.101, 379-385, 2007.

[11] M. E. Guynot, A. J. Ramos, L. Seto, P. Purroy, V. Sanchis, S. Marin. Antifungal activity of volatile compounds generated by essential oils against fungi commonly causing deterioration of bakery products, Journal of Applied Microbiology, Vol.94, , 893-899, 2003.

[12] M. Jamshidi, M. Barzegar, M. A. Sahari. Effect of gamma irradiation on the antioxidant and antimicrobial activities of cinnamon powder, Iranian Journal of Nutrition Sciences and Food Technology, Vol.7, No. 4, 61-70, 2012.

[13] A. Rajaei, M. Barzegar, A. Mohabati Mobarez, M. A. Sahari, Z. Hamidi-Esfahani. Antioxidant, antimicrobial and antimutagenicity activities of pistachio (Pistachia vera) green hull extract, Food and Chemical Toxicology, Vol.48, 107-112, 2010.

[14] M. S. A. Rahman, S. Thangaraj, M. S. Salique, K. Feroz khan, S. Esath Natheer. Antimicrobial and biochemical analysis of some spices extract against food spoilage pathogens, International Journal of Food Safety, Vol.12, 71-75, 2010.

[15] S. Zarringhalami, M. A. Sahari, M. Sattari. Antibacterial and preservative activities of commercial annatto extract (norbixin) in chemical defined medium and sausage, Green Farming, Vol.1, No.9, 18-21, 2008.

[16] S. Zarringhalami, M. A. Sahari, Z. Hamidi-Esfehani. Partial replacement of nitrite by annatto as a color additive in sausage, Meat Science, Vol.81, 281-284, 2009.

[17] B. S. M. Mahmoud, K. Yamazaki, K. Miyashita, S. II-Shik, C. Dong-Suk. T. Suzuki. Bacterial micro flora of carp (Cyprinus carpio) and its shelf life extension by essential oil compounds, Food Microbiology, Vol. 21, No. 6, 657-666, 2004.

[18] O. Mejlholm, P. Dalgaard. Antimicrobial effect of essential oils on the seafood spoilage microorganism Photobacterium phosphoreum in liquid media and fish products, Letters in Applied Microbiology, Vol.34, No.1, 27-31, 2002.

[19] E. Chouliara, A. Karatapanis, I. N. Savvaidis, M. G. Kontominas. Combined effect of oregano essential oil and modified atmosphere packaging on shelf life extension of fresh chicken breast meat, stored at $4 \mathrm{C}$, Food Microbiology, Vol.24, No.6, 607-17, 2007.

[20] S. Pezeshk, M. Rezaei, H. Hosseini. Effects of turmeric, shallot extracts, and their combination on quality characteristics of vacuum-packaged rainbow trout stored at 4 $\pm 1^{\circ} \mathrm{C}$, Journal of Food Science, Vol.76, No.6, 387-391, 2011.

[21] S. Berenji Ardestani, M. A. Sahari. Investigation of measurement methods of antioxidant activity and involved mechanisms, Journal of Pharmacy and Nutrition Sciences, Vol.3, 76-107, 2013.

[22] S. M. Ojagh, M. A. Sahari, M. Rezaei, S. V. Hosseini. Applicability of $\beta$-carotene and green tea polyphenols as two natural antioxidants in preservation of common kilka (Clupeonella cultriventris Caspia) with ice, International Journal of Agriculture: Research and Review, Vol.1, No.4, 174-181, 2011.

[23] S. Tang, J. P. Kerry, D. Sheehan, D. J. Buckley, P. A. Morrissey. Antioxidative effect of added tea catechins on susceptibility of cooked red meat, poultry and fish patties to lipid oxidation, Food Research International, Vol.34, 651-657, 2000.

[24] M. Karpińska, J. Borowski, M. Danowska-Oziewicz. The use of natural antioxidants in ready-to-serve food, Food Chemistry, Vol.72, 5-9, 2001.

[25] Y. T. Lin, R. G. Labbe, K. Shetty. Inhibition of Listeria monocytogenes in fish and meat systems by use of oregano and cranberry phytochemical synergies, Applied and Environmental Microbiology, Vol.70, 5672-5678, 2004. 
[26] B. Stonsaovapak, S. Saiyadthong. Antilisterial effects of ethanolic extracts of some edible Thai plants on refrigerated cooked pork, Maejo International Journal of Science and Technology, Vol.4, No.3, 540-546, 2010.

[27] A. Moure, J. Cruz, D. Franco, J. vM. Domĭnguez, J. Sineiro, H. Domǐnguez, M. José Núnez, J. C. Parajó. Natural antioxidants from residual sources, Food Chemistry, Vol.72, 145-171, 2001.

[28] M. B. Mielnik, S. Sem, B. Egelandsdal, G. Skrede. By-products from herbs essential oil production as ingredient in marinade for turkey thighs, LWT- Food Science and Technology, Vol.41, No.1, 93-100, 2008.

[29] S.R. Kanatt, R. Chander, A. Sharma. Antioxidant and antimicrobial activity of pomegranate peel extract improves the shelf life of chicken products, International Journal of Food Science and Technology, Vol.45, 216-222, 2010.

[30] H. Kordsardoui, M. Barzegar, M. A. Sahari. Antifungal property and rheological characteristics of Zataria multiflora Boiss essence in cake, National Congress Medicinal Plants, Sari University of Agricultural Sciences and Natural Resources, 610, 2011.

[31] M. Zangiabadi, M. A. Sahari, M. Barzegar, H. Naghi Badi. Zataria multiflora and Bunium persicum essential oils as two natural antioxidants, Journal of Medicinal Plants, Vol.11, No.41, 8-21, 2012.

[32] A. E. M. Abdalla, S. M. Darwish, E. H. E. Ayad, R. M. El-Hamahmy. Egyptian mango by-product 2: antioxidant and antimicrobial activities of extract and oil from mango seed kernel, Food Chemistry, Vol.103, No.4, 1141-1152, 2007.

[33] N. Vergara-Valencia, E. Granados-Perez, E. Agama-Acevedo, J. Tovar, J. Ruales, L. A. Bello-Perez. Fibre concentrate from mango fruit: characterization, associated antioxidant capacity and application as a bakery product ingredient, LWT, Lebensmittle-Wissenschaft and Technologie, Vol.40, 722-729, 2007.

[34] F. Darughe, M. Barzegar, M. A. Sahari. Antioxidant and Antifungal activities of coriander (Coriandrum sativum L.) essential oil in cake, International Food Research Journal, Vol.19, No.3, 1253-1260, 2012.

[35] A. F. Begnami, M. C. T. Duarte, V. Furletti, V. L. G. Rehder. Antimicrobial potential of Coriandarum sativum L. against different Candida species in vitro, Food Chemistry, Vol.118, 74-77, 2010.

[36] Z. Sabouri, M. Barzegar, M. A. Sahari. Antifungal effect of Echinacea purpurea L. extract on cake, National Congress Medicinal Plants, Sari University of Agricultural Sciences and Natural Resources, 511, 2011.

[37] L. P. S. Lean, S. Mohamed. Antioxidative and antimycotic effects of turmeric, lemon-grass, betel leaves, clove, black pepper leaves and Garcinia atriviridis on butter cakes, Journal of the Science of Food and Agriculture, Vol.79, 1817-1822, 1999.

[38] C. G. Rizzello, R. Coda, M. De Angelis, R. Di Cagno, P. Carnevali, M. Gobbetti. Longterm fungal inhibitory activity of water soluble extract from Amaranthus spp. seeds during storage of gluten-free and wheat flour breads, International Journal of Food Microbial, Vol.131, 189-196, 2009.

[39] M. I. Bhange, S. Iqbal, F. Anwar, M. Imran, M. Akhtar, M.
Zia-Ul-Haq. Antioxidant potential of rice bran extracts and its effects on stabilization of cookies under ambient storage, International Journal of Food Science and Technology, Vol.43, 776-779, 2008.

[40] Z. Noorolahi, M. A. Sahari, M. Barzegar, N. Doraki, H. Naghdi Badi. Evaluation of antioxidant and antimicrobial effects of cinnamon essential oil and echinacea extract in Kolompe, Journal of Medicinal Plants, Vol.12, No.45, 14-28, 2013.

[41] M. Khaki, M. A. Sahari, M. Barzegar. Evaluation of antioxidant and antimicrobial effects of chamomile (Matricaria chamomilla L.) essential oil on cake shelf life, Journal of Medicinal Plants, Vol.11, No.43, 9-18, 2012.

[42] M. Khaki, M. A. Sahari, M. Barzegar. Antimicrobial effect of neroli essential oil on cake, National Congress Medicinal Plants, Sari University of Agricultural Sciences and Natural Resources, 324, 2011.

[43] S. Y. Lee, S. Y. Gwon, S. J. Kim, B. K. Moon. Inhibitory effect of commercial green tea and rosemary leaf powders on the growth of food-borne pathogens in laboratory media and oriental-style rice cakes, Journal of Food Protection, Vol.72, No.5, 1107-1111, 2009.

[44] M. Darabi Momtaz, M. A. Sahari, M. Barzegar, S. Seif Hashemi. Antimicrobial effect of Lavandula angustifolia on some microbial parameters of buttermilk preservation, National Congress Medicinal Plants, Sari University of Agricultural Sciences and Natural Resources, 905, 2011.

[45] J. Gutierrez, C. Barry-Ryan, P. Bourke. Antimicrobial activity of plant essential oils using food model media: efficacy, synergistic potential and interactions with food components, Food Microbiology, Vol.26, 142-150, 2009.

[46] R. J. Owen, E. A. Palombo. Anti-listerial activity of ethanolic extracts of medicinal plants, Eremophila alternifolia and Eremophila duttonii, in food homogenates and milk, Food Control, Vol.18, 387-390, 2007.

[47] M. Khodaparast, M. Mehraban, A. Karazhyan, R. Najafi, S. Toosi. Effect of essential oil and extract of Ziziphora clinopodioides on yoghurt starter culture activity, World Applied Sciences Journal, Vol.2, No.3, 194-197, 2007.

[48] A. S. Vosoogh, M. Khomeiri, M. Kashani Nijad, S. M. Jafari. Effect of mint extract on the viability of probiotic bacteria in a native Iranian dairy drink (doogh), Journal of Agricultural Sciences and Natural Resources, Vol.16, No.1, 2009.

[49] M. Friedman, P. R. Henika, C. E. Levin, R. E. Mandrell. Antibacterial activities of plant essential oils and their components against Escherichia coli O157:H7 and Salmonella enterica in apple juice, Journal of Agricultural and Food Chemistry, Vol.52, 6042-6048, 2004.

[50] P. Nguyen, G. S. Mittal. Inactivation of naturally occurring microorganisms in tomato juice using pulsed electric field (PEF) with and without antimicrobials, Chemical Engineering and Processing, Vol.46, 360-365, 2007.

[51] M. Karapinar, I. Y. Sengun. Antimicrobial effect of koruk juice against Salmonella typhimurium on salad vegetables, Food Control, Vol.18, 702-706, 2007.

[52] D. Rosch, M. Bergmann, D. Knorr, L. W. Kroh. Structure-antioxidant efficiency relationships of phenolic compounds and their contribution to the antioxidant activity 
of sea buckthorn juice, Journal of Agricultural and Food Chemistry, Vol.51, No.15, 4233-4239, 2003.

[53] H. Vahidian, M. A. Sahari, M. Barzegar, H. Naghdi Badi. Application of Zataria multiflora Boiss and Satureja hortensis L. essential oils as two natural antioxidants in mayonnaise formulated with linseed oil, Journal of Medicinal Plants, Vol.11, No.43, 69-79, 2012.

[54] F. Ayoughi, M. Barzegar, M. A. Sahari, H. Naghdibadi. Chemical composition of essential oils of Artemisia dracunculus L. and endemic Matricaria chamomilla L. and an evaluation of their antioxidant effects, Journal of Agricultural Sciences and Technology, Vol.13, 79-88, 2011.

[55] R. G. K. Leuschner, J. Zamparini. Effect of spices on growth and survival of E. coli $\mathrm{O} 157$ and Salmonella enterica serovar enteritidis in broth model systems and mayonnaise, Food Control, Vol.13, 399-404, 2002.

[56] M. D. Lopez, M. J. Jordan, M. J. Pascual-Villalobos. Toxic compounds in essential oils of coriander, caraway and basil active against stored rice pests, Journal of Stored Products Researches, Vol.44, No.3, 273-278, 2008.

[57] S. Burt. Essential oils: their antibacterial properties and potential applications in foods - A review, International Journal of Food Microbiology, Vol.94, No.3, 223-253, 2004.

[58] F. Tornuk, H. Cankurt, I. Ozturk, O. Saqdic, H. Yektim. Efficacy of various plant hydrosols as natural food sanitizers in reducing Escherichia coli O157:H7 and Salmonella typhimurium on fresh cut carrots and apples, International Journal of Food Microbiology, Vol.148, No.1, 30-35, 2011

[59] S. J. Lee, K. Umano, T. Shibamoto, K. G. Lee. Identification of volatile components in basil (Ocimum basilicum L.) and thyme leaves (Thymus vulgaris L.) and their antioxidant properties, Food Chemistry, Vol.91, No.1, 131-137, 2005.

[60] P. Suppaukul, J. Miltz, S. Kees, S. Bigger. Antimicrobial properties of basil and its possible application in food packaging, Journal of Agriculture and Food Chemistry, Vol.51, No.11, 3197-3207, 2003.

[61] M. M. Tajkarimi, S. A. Ibrahim, D. O. Cliver. Antimicrobial herb and spice compounds in food, Food Control, Vol.21, 1199-1218, 2010.

[62] P. V. Nielsen, R. Rios. Inhibition of fungal growth on bread by volatile compounds from spices and herbs and the possible application in active packaging with special emphasis on mustard essential oil, Journal of Food Microbial, Vol.60, No.2-3, 219-229, 2000.

[63] H. Soleimani, M. Barzegar, M. A. Sahari, H. Naghdi Badi. An investigation on the antioxidant activities of Hyssopus officinalis L. and Echinacea purpurea L. plant extracts in oil model system, Journal of Medicinal Plants, Vol.10, No.37, 2011.

[64] F. Ayoughi, M. Barzegar, M. A. Sahari, H. Naghdi Badi. Antioxidant effect of dill (Anethum graveolens Boiss) oil in crude soybean oil and comparison with chemical antioxidants, Journal of Medicinal Plants, Vol.8, No.30, 71-83, 2009.

[65] M. A. Sahari, M. Amooi. Tea seed oil: extraction, compositions, applications, functional and antioxidant properties, Academia Journal of Medicinal Plants, Vol.1, No.4, 068-079, 2013.

[66] N. U. Wanasundara, F. Shahidi. Stabilization of sea blubber and menhaden oils with green tea catechins, Journal of American Oil Chemists' Society, Vol.42, 1280-1290, 1996.

[67] N. U. Wanasundara, F. Shahidi. Antioxidant and pro-oxidant activity of green tea extracts in marine oils, Food Chemistry, Vol.63, No.3, 335-342, 1998.

[68] M. Fazel, M. A. Sahari, M. Barzegar. Comparison of tea and sesame seeds oils as two natural antioxidants in fish oil model system by radical scavenging activity, International Journal of Food Science and Nutrition, Vol.60, No.7, 567-576, 2009.

[69] A. Fathi, M. A. Sahari, M. Zangiabadi, M. Barzegar. Application of Satureja hortensis L. and Ztaria multiflora Boiss essential oils as two natural antioxidants in soybean oil during microwave heating, Journal of Medicinal Plants, Vol.10, No.39, 12-21, 2011.

[70] A. Fathi, M. A. Sahari, M. Barzegar, H. Naghdi Badi. Antioxidant activity of Satureja hortensis L. essential oil and its application in safflower oil, Journal of Medicinal Plants, Vol.12, No.45, 51-67, 2013.

[71] M. Taha Nejad, M. Barzegar, M. A. Sahari, H. Naghdi Badi, Evaluation of antioxidant activity of Lavandula angustifolia essential oil in crude soybean oil, Journal of Medicinal Plants, Vol.8, 127-140, 2010.

[72] M. Taha Nejad, M. Barzegar, M. A. Sahari, H. Naghdi Badi. Evaluation of antiradical activity of Malva sylvestris L. essence and its potential usage in oil system, Journal of Medicinal Plants, Vol. 42, 86-97, 2012. 